White House science advisor takes the reins after slow start

Washington

ONE year into his job as President Reagan's science advisor and director of the Office of Science and Technology Policy, William R. Graham seems ready to take a somewhat higher profile in national and international science policymaking. Graham is a softly spoken man who has so far shunned the limelight that was much loved by some of his illustrious predecessors. His first important public appearance was not until the summer when he shared the stage with Reagan and the Secretaries of Defense, Energy and State during the opening speeches at the government-sponsored meeting on the commercial applications of superconductors (see Nature 328, 469; 1987).

Reagan nominated Graham to replace George A. Keyworth II as his science advisor in June 1986, six months after Keyworth left the post. Inexplicably, the White House neglected to send Graham's nomination to the Senate for months, and it was not until 1 October that the Senate confirmed Graham's nomination. But now it seems that Graham has access to White House inner circles, including the president whom he describes as having a "strong interest in science and technology" which at times "stretches" Graham's capacity to keep up with his questions. On 1 October, for example,

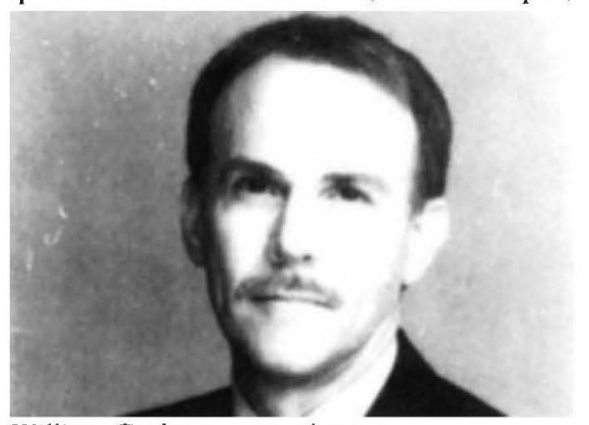

William Graham - opening up

when Graham, trained in physics and electronics, quickly had to become an Earth scientist. The president wanted an immediate briefing on the implications of that morning's earthquake in Los Angeles (see p.479) for other geological faults in the region.

Judging by Graham's activity in two of this summer's key domestic issues - how the spread of AIDS (acquired immune deficiency syndrome) should be contained, and how best to stimulate research on the new superconductors - he seems to see his role, at the top of the pyramid, as one of ensuring efficient inter-departmental coordination. On the international front he is more of an innovator.

Graham sees science and technology, particularly basic science, emerging as important new factors in international relations. But unlike other key areas of diplomatic activity no international body exists to look after the interests of basic research. Graham looks towards "establishing an international framework for basic sicence" with the first steps being taken at the OECD (Organization for Economic Cooperation and Development) ministerial meeting in Paris at the end of this month. He looks for support for the notion that basic scientific research is a shared responsibility for all industrialized countries. Guaranteed access to basic research laboratories, regardless of the institutional structures in which they are found, is one component of that responsibility. Another, difficult to realize, will be to find a common view on intellectual property rights so that they do not become a barrier to free exchange of research.

Is Graham thinking of Japan as a country that has evaded its responsibilities of support for basic research? He says that "Japan shouldn't be take as a role model for other countries". Rather than taking their basic research from elsewhere, developing countries should build basic research infrastructure alongside industrial development. The special problems that the United States has with Japan will be taken up this month in formal negotiations over the US-Japan science cooperation agreement.

To match Japan's vigour in creating new products, Graham agrees with the thrust of the National Science Foundation's initiatives on giving industry better access to the universities' basic research. "US industry", he says, "must become more aggressive in assimilating basic research" and make room for it "in long-range plans". The role of government he sees as a "catalyst" in a two-way flow between universities and industry. But he does not endorse any one unique solution; "the United States is big enough to tolerate quite a bit of diversity".

Alun Anderson \& Joseph Palca

\title{
California decides to speed up testing of new AIDS drugs
}

\section{San Francisco}

CONCERN that new drugs for the treatment of AIDS (acquired immune deficiency syndrome) are not reaching the market place quickly enough has led the state of California to declare plans to establish its own drug-testing programme, independent of the federal Food and Drug Administration (FDA). Legislation for the programme, passed by the state government last week, was welcomed by AIDS sufferers' organizations which have long seen the FDA as lacking openmindedness and a sense of urgency when considering new drugs. But critics contend that the real problem is that there are simply not enough good candidate drugs.

A panel should be at work by the end of the year reviewing applications for in-state human testing of drugs made in California, and possibly licensing the instate use of drugs that show effectiveness in human trials.

Paul Volberding, an AIDS drug researcher at the University of California at San Francisco (UCSF), and a member of the drug-review panel, said the law will add an unnecessary layer of bureaucracy and he worries that the panel lacks the necessary expertise to evaluate preliminary animal testing of new drugs, and may give approval for human trial to drugs that are unsafe.

Volberding said the FDA has streamlined the approval process for AIDS drugs by working with drug manufacturers and testers. In the case of $\mathrm{AZT}$, now licensed under the name of Retrovir, permission to begin human studies was granted within a few days of receipt of the application.

Although supporters of the law have faith in the expertise of the Californian panel, they hope it will be prepared to consider new drugs and drugs such as ribovirin, dismissed by the FDA after two trials, one of which gave a positive result, but was shown to be flawed.

Hundreds of AIDS patients are individually obtaining ribovirin in Mexico, said California state assemblyman Bill Filante, author of the bill, but no data can be gathered on their progress. Filante wants to see some of these people brought into a California study, so they can be medically supervised and the data used for evaluation of the drug's effectiveness.

Some critics of the law worry that the exclusive testing of drugs in California will draw AIDS patients to the state, but Filante points out that California is already a magnet because of its highly developed system for AIDS care.

Marcus Conant, an AIDS researcher at UCSF, noted that the law may bring industry to the state, if companies choose to move their drug-developing operations to take advantage of California's testing.

A source of funding for the drug testing has not yet been assured, although $\$ 500,000$ has been appropriated for startup costs. Governor George Deukmejian recently vetoed a bill that would have provided tax credits to those who contributed funds to the programme. Marcia Barinaga 